\title{
A Proposed Conceptual Framework on the Adoption of Sustainable Agricultural Practices: The Role of Network Contact Frequency and Institutional Trust
}

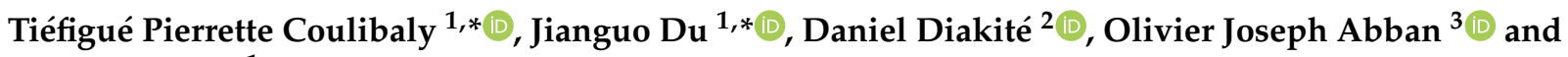 \\ Elvis Kouakou ${ }^{1}$ \\ 1 School of Management, Jiangsu University, Zhenjiang 212013, China; elviskouakou@yahoo.fr \\ 2 Faculty of Agriculture and Food Sciences, LAVAL University, Quebec, QC G1V 0A6, Canada; \\ dandiakite@gmail.com \\ 3 Institute of Applied Systems and Analysis (IASA), School of Mathematical Science, Jiangsu University, \\ Zhenjiang 212013, China; olivierjosephs@yahoo.com \\ * Correspondence: coulibaly_pierrette@yahoo.fr (T.P.C.); djg@ujs.edu.cn (J.D.)
}

check for updates

Citation: Coulibaly, T.P.; Du, J.; Diakité, D.; Abban, O.J.; Kouakou, E. A Proposed Conceptual Framework on the Adoption of Sustainable Agricultural Practices: The Role of Network Contact Frequency and Institutional Trust. Sustainability 2021, 13, 2206. https://doi.org/10.3390/ su13042206

Academic Editor: Manuel González de Molina

Received: 20 January 2021

Accepted: 11 February 2021

Published: 18 February 2021

Publisher's Note: MDPI stays neutral with regard to jurisdictional claims in published maps and institutional affiliations.

Copyright: (c) 2021 by the authors. Licensee MDPI, Basel, Switzerland. This article is an open access article distributed under the terms and conditions of the Creative Commons Attribution (CC BY) license (https:/ / creativecommons.org/licenses/by/ $4.0 /)$.

\begin{abstract}
To promote environmental changes in agriculture, the use of sustainable agricultural practices was considered to be crucial. Several factors have been identified that affect farmers in their decision to implement sustainable agricultural practices effectively. Despite this, the rate of adoption of sustainable agricultural practices remains below the planned level, and it is important to know how to solve this issue. In this paper, we propose a model based on the theory of planned behavior and the norm activation theory with the integration of network contact frequency as a mediator and institutional trust as a moderator to fill "the intention-behavior" gap.
\end{abstract}

Keywords: sustainable agricultural practices; farmer's decision; social network contact frequency; institutional trust

\section{Introduction}

Agriculture is one of the most essential practices for the future of humanity, but it has major environmental impacts [1], such as climate change, soil degradation, pollutants, irrigation problems, waste, and deforestation [2]. According to Godfray et al. [3], the world's population is projected to hit around 9 billion by 2050, which means more food will be required to feed the fast-growing population. Therefore, the FAO (Food and Agriculture Organization) stresses the need for farmers to respond to the task and grow more food to meet the increasing demand towards sustainability. One of the biggest problems of nations now is to establish sustainable agriculture. There is a variety of definitions of sustainable agriculture according to the issues motivating concern [4]. It can be view as an ideology with MacRae (1990) [5] who defined it as "a philosophy and system of farming. It has its roots in a set of values that reflect a state of empowerment, of Awareness of ecological and social realities, and of one's ability to take effective action." Francis et al., (1987) [6], on the other hand have defined sustainable agriculture as a set of strategies: "a management strategy which helps the producers to choose hybrids and varieties, a soil fertility package, a pest management approach, a tillage system, and a crop rotation to reduce costs of purchased inputs, minimize the impact of the system on the immediate and the off-farm environment, and provide a sustained level of production and profit from farming". As an ability to fulfill a set of goals we have the definition of Harwood (1990) [7] where sustainable agriculture is an "agriculture that can evolve indefinitely toward greater human utility, greater efficiency of resource use, and a balance with the environment that is favorable both to humans and to most other species". Among all this range of definitions, the main point is that sustainable agriculture put emphasis on the environmental, social, and economic issues in agriculture for the needs of present and future generations [8]. 
According to the FAO (Food Agricultural Organization), "the goal of sustainable agriculture is to meet society's food and textile needs in the present without compromising the ability of future generations to meet their own needs" [9]. It is in this attempt that sustainable agricultural practices (SAPs) have been developed [10]. Those practices mainly involve ensuring efficient and proper usage of non-renewable resources in a way that makes it possible to be able to maintain the economic viability of activities on a farm as well as develop a generally acceptable standard of life and protect the environment. In the agricultural system, farmers are among the most essential groups when it comes to natural resources management, and they have a critical role to play in the conservation of the ecosystem. Indeed, unsustainable human behavior is responsible for global environmental threats. Therefore, the promotion of sustainable agricultural practices at the farmers level is necessary to ensure agricultural sustainability [2]. The process of implementing sustainable agricultural practices is often complicated [11]. The literature on the factors affecting farmers' behavior is pervasive, and an extensive wide range of internal and external factors have been established which have an effect on the adoption of various forms of SAPs. Researchers often hypothesize farmers' socio-economic characteristics to impact the adoption of SAPs. Age, education, farm experience, income, land ownership, and gender had a significant influence on the adoption of SAPs [12-16]. Apart from socioeconomic factors, psychological factors have also been explored and classified by Dessart et al. (2019) [17] into three groups according to their distance from decision making. Exogenous factors like social capital [18], extension services and group discussion [19], training (NGO/institution) [20], public-private involvement [21], and sponsorship/fund [22] also have an impact on farmers sustainable agriculture practice adoption. Despite this, the adoption rate of SAPs remains below expected levels [16] and there is a need to understand why. To do so, the purpose of the current research is to review and integrate primary constructs from the theory of planned behavior, norm activation theory, and adding network contact frequency, and institutional trust in one coherent robust model to fill this gap between intention and behavior. The model combines and extends the existing literature to advance the body of knowledge concerning SAP adoption. Thus, we present the theories and different constructs involved in the SAPs adoption process which forms the proposed conceptual framework.

The remaining sections are as follows: Section 2 discusses theoretical background, followed by Section 3, conceptual framework and propositions, then finally Section 4 with the conclusion.

\section{Theoretical Background}

A theory is a collection of interrelated definitions, concepts, and propositions that predicts or explains events or circumstances by specifying correlation between the variables [23]. Many different kinds of theories and models, like the theory of reasoned action, the value-belief-norms theory, the behavioral change model, or the diffusion of innovation model, have been used by researchers to explain behaviors like the adoption of sustainable agricultural practices [24]. Among those theories, the theory of planned behavior (TPB) and the norms activation theory (NAT) will be the theoretical base for this model. Moreover, Jackson (2005) in his review on behavioral change, stated that the TPB remains an adjusted expectancy-value model [25], and NAT is considered to be one of the most potent theories when it comes to the environment [26]. We believe those two theories are highly appropriate for the context of sustainable agricultural practices, as the adoption of sustainable agriculture practice is a social behavior learned within the organization through the erudition of such behaviors on the part of other farmers or institutions. Moreover, integrated models of behavior that incorporate both social-psychological and contextual variables have been found to have a higher prediction power [25]. Si et al. (2019) [27] also recommended that future environmental research using the TPB should incorporate supplementary theories, construct from diverse disciplines, and consider more relevant external factors to present better predictions and implications. We propose to integrate 
two external factors, network contact frequency and institutional trust as mediators and moderators in the SAP adoption intention-behavior relation into our model.

\subsection{The Theory of Planned Behavior}

The theory of planned behavior (TBP) was first introduced by Fishbein and Ajzen (1975) [28] as the theory of reasoned action to predict an individual's intention to engage in a practice at a specific time or place [28] and was updated by Ajzen in 1991 [29]. The TPB aims to predict and explain human behavior through a range of personal and social factors. According to this theoretical model, the main factor in predicting an individual's behavior is their intention. The intention includes the motivational element needed to generate the behavior and indicates how willing an individual is to make efforts to produce it. This central factor would arise from three sets of determinants: attitudes, subjective norms, and perception of control as shown in Figure 1.

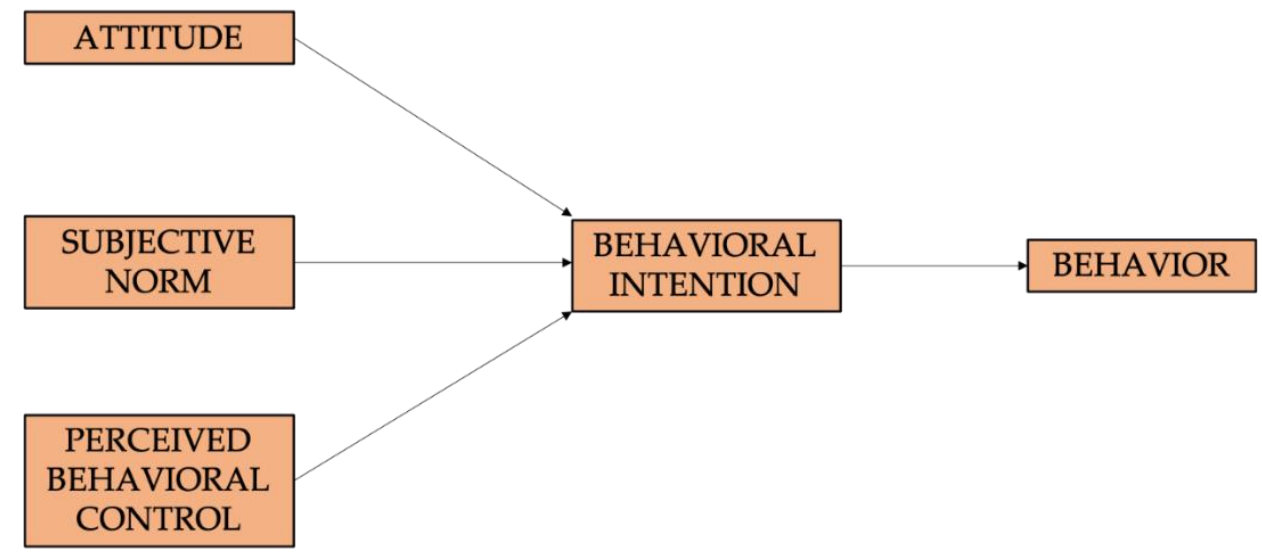

Figure 1. The theory of planned behavior, Ajzen (1991).

First, attitudes represent a person's positive or negative assessment of behavior. These attitudes are formed from the individual's beliefs about the behavior. This behavior is associated with a set of attributes, such as its characteristics and consequences which are evaluated positively or negatively. As a result of this assessment, the individual links the behavior and its implications or its cost of adoption. Attitudes arise from this link, and its influence is in proportion to the subjective likelihood that behavior will have specific consequences [29]. Therefore, attitudes are the result of the individual's beliefs and values regarding a particular behavior. Secondly, the subjective norm represents the perceived social pressure of the individual, whether in society in general or in their surroundings, to behave in a certain way [29]. This standard is based on the normative beliefs of the individual, that is, the behavior that he believes to be most accep given their social environment. The strength of normative beliefs, coupled with the individual's motivation or willingness to do so, will determine the importance of the global subjective standard in predicting his or her intention towards the behavior. Finally, perceived behavioral control refers to a person's assessment of the difficulty or ease with which they will be able to engage in a behavior [29]. Precisely, perceived behavioral control reflects the beliefs about the presence of internal or external factors of the individual, that facilitate or hinder the adoption of behavior [30]. Internal factors include perceived capacity and willpower, while external factors include task-specific requests and the actions of others [31].

\subsection{The Norm Activation Theory}

The norm activation theory (NAT) [32], illustrated by Figure 2, states that behavior is influenced by the personal norm, which itself is determined by the awareness of the problem and its consequences, as well as the attribution of responsibility. According to Schwartz [32], the realization of such behavior depends intimately on the activation of 
the personal standard or moral standard. It corresponds to the sense of moral obligation to act, from an ethical point of view. Thus, there is no external pressure that pushes the individual to adopt the target behavior. Still, it is for the sake of consistency, internal coherence between actions and values, or convictions. The NAT has been successfully used to predict a variety of prosocial intentions and behaviors, such as donating bone marrow or donating blood [33]. A prosocial behavior is considered a behavior that benefits other individuals or even the society as a whole [34]. Sustainable agricultural practice can also be classified as a prosocial behavior because it implies the whole community may benefit from its adoption when protecting the environment for future generations [35,36]. Furthermore, during the past years, there have been many studies that support NAT in the environmental context, such as recycling [37], energy conservation [38], willingness to pay for environmental protection [39], and general pro-environmental behavior [40].

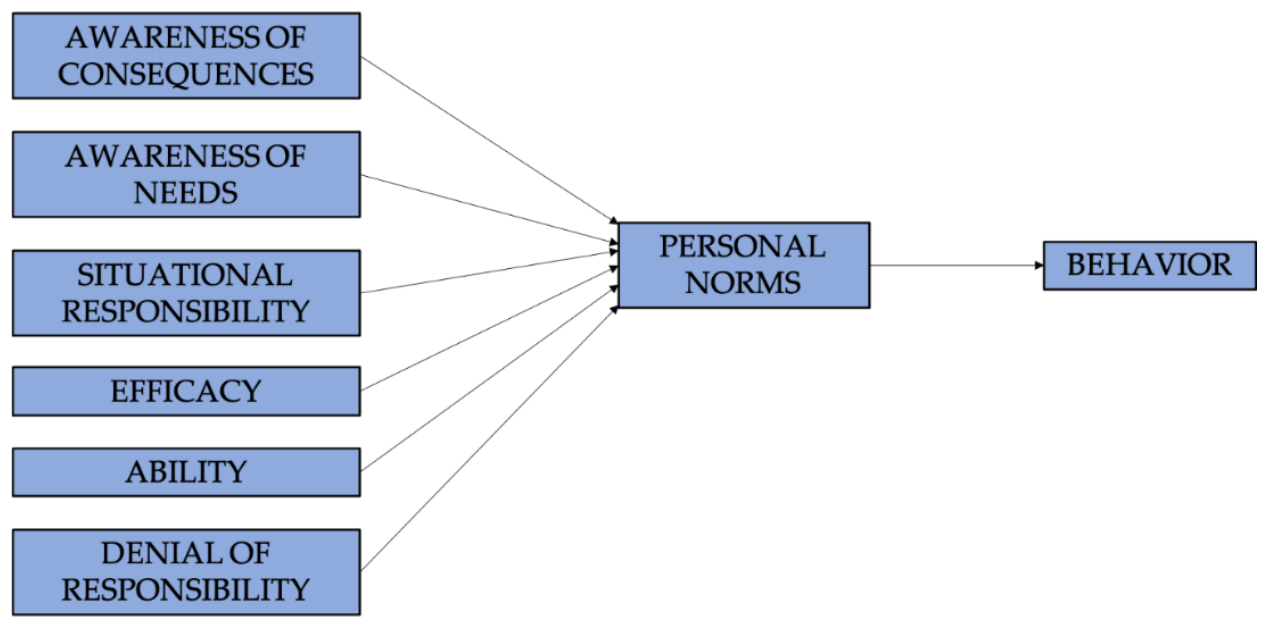

Figure 2. The norm activation theory-NAT (Schwartz, 1977).

\subsection{Network Contact Frequency}

Human communities incorporate a collection of networks, inside which individuals are related to institutions or individuals through relational ties. Knowledge flows and is shared through these relational ties. Social networks have an impact on the propagation of innovation through social learning, mutual appraisal, social impact, and collective action processes [41]. In social network theory, the decision-making mechanism of the actors is believed to be affected by four key elements that are: their role within one or a subset of the social networks in which they are participants, the frequency and form of links that connect them to other actors within such networks, the role and degree of control of other actors, and the forms of contact between actors within the network [42]. Farmers receive technological knowledge through their social network, address the expected return of technology, and make adoption choices. [43]. Indeed, one of the functions of a social network is to provide information, and studies of social networks propose that the likelihood of information transmission might depend on the strength of the tie [44]. Contact frequency is presented by Granovetter (1973) [45] as one of the three factors that define tie strength. Previous studies [46-48] of agricultural technology promotion and adoption mostly focuses on farmers' network structure and paid less attention to the interaction effect of social network [43]. Following Joffre et al. (2020) [49], who states that "frequency of interaction with relevant network partners is one of the factors influencing adoption of technologies and practices", we proposed to use frequency of interaction with different SAP actors of farmers' network as a mediator between a farmer's intention and behavior in an integrated model of the theory of planned behavior and norms activation theory. 


\subsection{Institutional Trust}

Trust is a construct with multiple dimensions and has been studied in diverse disciplines. It is an essential factor that affects social interactions and exchanges [50]. It can be defined as a favorable expectation of future actions of others [51] or as a psychological state encompassing the intention to accept vulnerability to the actions of another party based on the anticipation that the other will behave in a particular way that is desirable to the person [52]. In the case of institutions, trust is an attitude toward a specific institution characterized by positive expectations that the institution will appropriately fulfill its functions [53]. Concerning sustainable behavior, institutional trust is associated with a greater willingness to make economic sacrifices for the environment [54]. Moreover, when individual trust institution, they are more likely to comply voluntarily with their directives [55].

\section{Conceptual Framework and Propositions}

This section is presented in two main subsections. The first subsection presents the proposed conceptual framework, and the second part defines the different constructs of this framework and the proposition development process based on the theories.

\subsection{Conceptual Framework}

A conceptual model is a structure that the researcher believes will help describe a phenomenon's natural development to be investigated [56]. It is the researcher's way of exploring the problem [57] or situation that needs solution. It is related to the concepts, empirical studies, and essential theories used in promoting and systemizing the knowledge adopted by the researcher [58].

Figure 3 below illustrates the proposed framework of SAPs adoption, which is based on the TPB and NAT. Updates were made to the TPB to enhance its explanatory capacity in different contexts [59]. For example, Sumaedi Sik et al. (2016) have integrated the TPB with the value theory and signaling theory to explain public transport passengers' intention to reuse [60]. Jacobs et al. (2011) used an integrated model of TPB and self-determination theory to explain exercise and dietary behaviors in a randomized controlled trial [61]. Concerning the environmental context, an integrated model of TPB and the NAT has been used by Liu et al. (2017) to predict individuals' intention to reduce car use [62], to predict waste sorting behavior by Setiawan et al. (2020) [63], or by Rezaei et al. (2019) to study drivers of farmers' intention to use integrated pest management [64]. In this study, we propose a research model integrating the TPB and the NAT where we have farmers' intention as a direct predictor of SAP's adoption. Then, following Bamberg and Möser (2007) [65], we have attitude, personal norms, and perceived behavioral control that directly influence SAP's adoption intention. In fact, adding personal moral norm as an additional construct to the TPB significantly increased the original model's explanatory power [66]. As far as they are concerned, attitude and personal norms are predicted by awareness of consequences [62] and subjective norm [65]. Finally, we introduce networking contact frequency as a mediator and institutional trust as a moderator in the relation between intention and the SAP's adoption because a better understanding of causal interactions is provided by both mediating and moderating relationships [67]. The next section will explain the propositions from the conceptual framework below.

\subsection{Propositions Development}

This section of the study discusses the various propositions resulting from the conceptual framework below. 


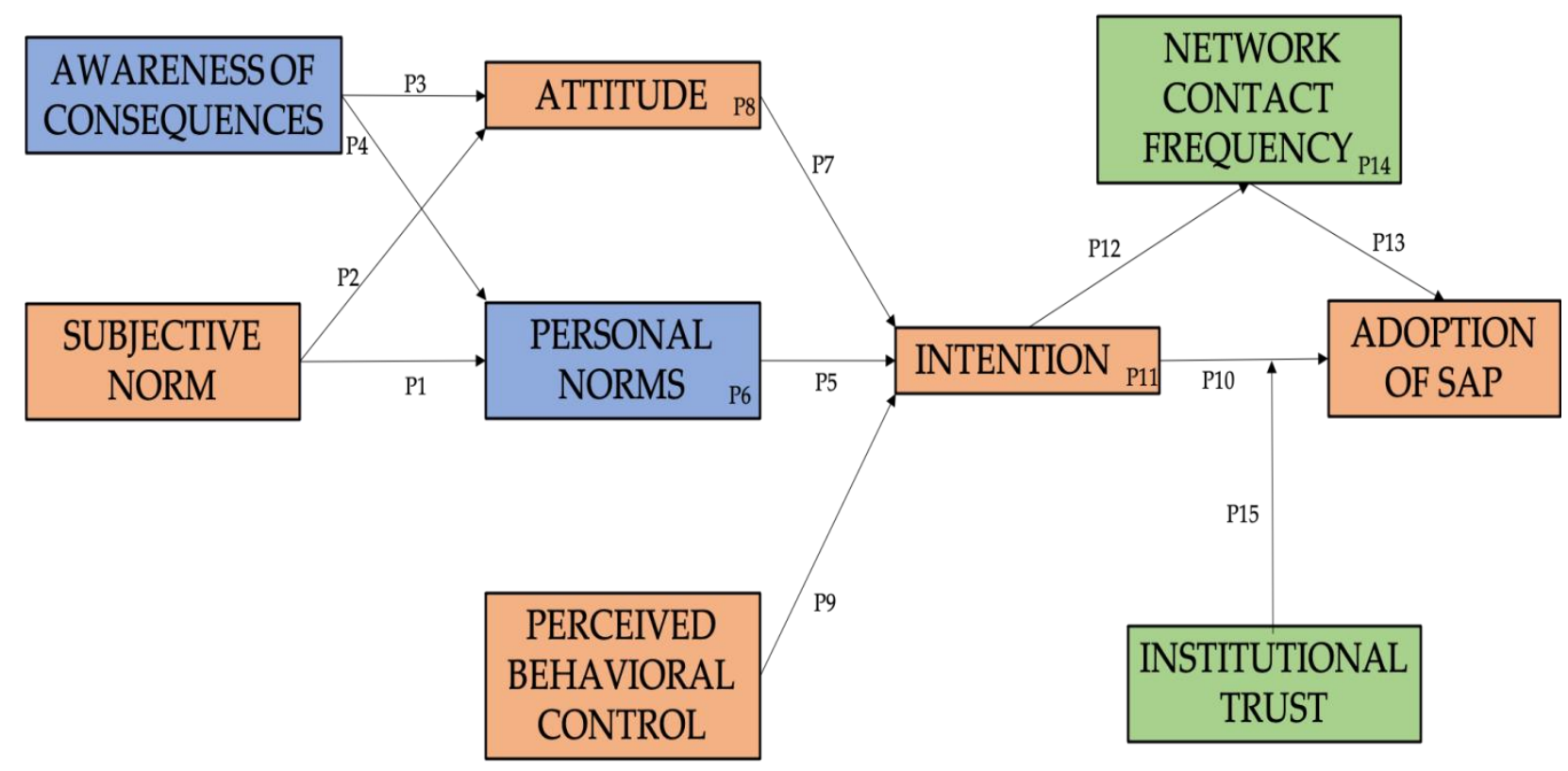

Figure 3. The proposed conceptual framework of sustainable agricultural practices (SAPs) adoption.

3.2.1. The Effect of Subjective Norm on Attitude toward SAPs and Personal Ecological Norm

The concept of subjective norm alternatively called social norm is one of the critical variables in the theory of planned behavior (TPB) [29]. It has been recognized as a core element of motivation and action and as a vital mechanism for behavioral influence and improvement, even though the concept of subjective norm is still relatively underused within the environmental area [68]. It is defined as the perceived expectations of other people [69]. In existing studies in environmental behavior like Park and Ha (2014) [37] for consumer recycling behavior and Zhang et al. (2017) [70] for citizen environmental complaint, subjective norm has been found to affect attitude toward behavior directly. The contribution of subjective norm to personal norms indicated that people used subjective norm as information to determine whether a behavior was morally right or wrong [71]. Accordingly, this study posits that subjective norm is a direct predictor of attitude toward SAPs and personal ecological norm.

Proposition 1 (P1): Subjective norm is positively related to attitude toward SAPs.

Proposition 2 (P2): Subjective norm is positively related to personal ecological norm.

3.2.2. The Effect of Awareness of Consequences on Attitude toward SAPs and Personal Ecological Norm

Awareness of consequences is a construct that comes from the norm activation theory. This theory suggests that awareness of consequences is a key factor to activate a person's personal obligation to perform a behavior [37]. This means that the higher the people's awareness of the positive impact of the adoption of sustainable agricultural practices, the more they will be able to feel social pressure to adopt it and to form favorable judgments about it. Liu et al. (2017) [62] and Han (2014) [72] have proven that awareness of consequences is positively correlated to personal norms and attitude toward pro-environmental intention like reduction of car use or environmentally responsible convention attendance [71]. Based on their finding, we made the following propositions:

Proposition 3 (P3): Awareness of consequences is positively related to attitude toward SAPs.

Proposition 4 (P4): Awareness of consequences is positively related to personal ecological norm. 


\subsubsection{The effect of Personal Ecological Norm on Intention to Adopt SAPs}

Personal norm is defined as self-expectations that are based on internalized values [40]. It reflects commitment with internalized values and is experienced as feelings of personal obligation to engage in a particular behavior [32]. Previous studies have shown that personal norms are positively related to pro-environmental behavior [69,73]. For example, Nordlund and Garvill (2013) [74] and Lui et al. (2017) [62] have demonstrated that people who feel a moral obligation to protect the environment are also more likely to intend to reduce personal car use. This is also true with Bamberg et al. (2007) [75] concerning the intention to use public transportation or with Thøgersen and Ölander (2006) [76] when it comes to purchase organic food products. Moreover, Zhang et al. (2017) [70] and Thøgersen (2006) [69] also confirmed the indirect effect of subjective norm and awareness of consequences on the behavioral intention by way of personal norms. We therefore make these propositions:

Proposition 5 (P5): Personal ecological norm is positively related to intention to adopt SAPs.

Proposition 6-a (P6-a): Personal ecological norm mediates the relationship between subjective norm and intention to adopts SAPs.

Proposition 6-b (P6-b): Personal ecological norm mediates and the relationship between awareness of consequences and intention to adopt SAPs.

\subsubsection{The Effect of Attitude toward SAPs on Intention to Adopt SAPs}

According to the theory of planned behavior, attitudes are the judgments that people make about the behavior they like or dislike. The more positive a person's attitude towards a behavior, the greater the behavioral intention a person will have [29]. Asadi et al. (2015) [77] used an integrated model of the TPB to investigate the decision to adopt green information technology (IT). The results of their study show that there is a direct and positive relationship between attitude towards green IT and behavioral intention to use green IT. Mastrangelo et al. (2013) [78] found that attitude had an important role as a driver of intention regarding forest conservation. Furthermore, Zhang et al. (2017) [70] stated that attitude significantly mediated the effect between awareness of consequences and intention and the relationship between subjective norm and behavioral intention of environmental complaint. Therefore, the following hypothesis is put forward:

Proposition 7 (P7): Attitude toward SAPs is positively related to intention to adopt SAPs.

Proposition 8-a (P8-a): Attitude toward SAPs mediates the relationship between subjective norm and intention to adopts SAPs.

Proposition 8-b (P8-b): Attitude toward SAPs mediates the relationship between Awareness of consequences and intention to adopt SAPs.

\subsubsection{The Effect of Perceived Behavioral Control on Intention to Adopt SAPs}

Perceived behavioral control (PBC) is defined as the perception of the difficulty of enacting a behavior [79]. With attitude and perceived norms, $\mathrm{PBC}$ is the third immediate predictor of behavioral intention in the TBP. It was found to have a significant influence on pro-environmental behavior intention like purchasing organic food [66], citizens' environmental complaints [70], adoption of green information technology [77], or car transport reduction [62]. Hence, it is proposed that:

Proposition 9 (P9): Perceived behavioral control is positively related to intention to adopts SAPs. 


\subsubsection{The Effect of Intention to Adopt SAPs on SAPs Adoption}

Intention to adopt a particular behavior is a key element in the theory of planned behavior, and the greater the intention to engage in a behavior, the greater the likelihood to behave appropriately [80]. It is the willingness and determination put up by the people that form behavior. Behavioral intention refers to a person's subjective probability that he will perform some behavior [28]. The TPB says that behavior is mainly driven by the intention to perform, so the main predictor of a behavior is the intention. This relationship has been proven by many researchers [81]. Dalvi Esfahani et al. (2015) [82] results showed that intention to adopt green IS gained the first rank among the other factors regarding the importance of its influence on adoption behavior. This is also true with Zhang et al. (2020) [83] concerning Chinese resident waste classification. Bamberg and Möser (2007) [65] confirmed that pro-environmental behavioral intention mediates the impact of attitude, $\mathrm{PBC}$, and moral norm on pro-environmental behavior. Following their results, we made the propositions below:

Proposition 10 (P10): Intention to adopt SAPs is positively related to adoption of SAPS.

Proposition 11-a (P11-a): Intention to adopt SAPs mediates the relationship between attitude toward SAP and adoption of SAPS.

Proposition 11-b (P11-b): Intention to adopt SAPs mediates the relationship between personal ecological norm and adoption of SAPs.

Proposition 11-c (P11-c): Intention to adopt SAPs mediates the relationship between Perceived behavioral control and adoption of SAPs.

3.2.7. The Mediation Effect of Network Contact Frequency in the Relationship between Intention to Adopt SAPs and the Adoption of SAPs

Interaction with various types of actors may be necessary for the accumulation of relevant information and expertise in order to realize different types of behavior, such as SAPs [84]. Knowledge institutes, like cooperative, private and public institutes, government agencies, and NGOs may be important because they aim at improving farmers knowledge. Frequency of contact is considered an important relational trait, which allows the transfer of complex knowledge and information involved in innovation [85]. Since interaction leads to knowledge acquisition, as individuals interact more, they share more knowledge [86]. Joffre et al. (2020) [49], in their study about the adoption of aquaculture technology and practices, showed that interactions with extension services and input retailers positively predicted adoption of water quality practices, disease control practices, and feed input practices. Moreover, interaction frequency with extension service has been identified as a mediator that can explain the relationship between clustering and adoption of water quality management practices. Following them, we proposed that:

Proposition 12 (P12): Intention to adopt SAPs is positively related to networking contact frequency.

Proposition 13 (P13): Networking contact frequency is positively related to adoption of SAPs.

Proposition 14 (P14): Networking contact frequency mediates the relation between intention to adopt SAPs and the adoption of SAPs.

3.2.8. The Moderating Effect of Institutional Trust in the Relationship between Intention to Adopt SAPs and the Adoption of SAPs

Institutional trust can be described as the needed conditions in place to enable one to anticipate a successful outcome in an endeavor or aspect of one's life [87]. It describes trust towards public institutions, both non-profit and government agencies, and affects farmers' decisions to join or exit agricultural cooperatives and their willingness to participate in 
other forms of collective action, including those designed to provide positive environmental and economic outcomes [88]. According to Rehman et al. (2019) [89], trust significantly moderates the relationship between consumer purchase intention and internet shopping behavior. In addition, individuals with a higher level of institutional trust are more likely to behave more responsibly with the environment than their counterparts [90]. This led us to make the following proposition:

Proposition 15 (P15): Institutional trust moderates the relationship between intention to adopt $S A P S$ and adoption of SAPS.

\section{Conclusions}

Increasing the adoption rate of SAP will lead to the reduction of the negative environmental impact of agriculture, and that is the ultimate goal of research in sustainable agriculture. An insight of the theory-based approach is necessary to deeply understand the underlying factors that will lead farmers to adopt SAPs. In this paper, we made several propositions based on an integrated model of the TPB and NAT with the mediating role of social network frequency and the moderating role of institutional trust in the intentionbehavior relation, to get a better understanding of farmers' SAP adoption. While certain people will intend to change their behavior, they may not be taking any concrete action to do so, and this disparity is referred to as "intention-behavior gap". This research addressed constructs that can help decision-makers bridge the gap between farmers' intention-action and translate their intentions into sustainable behavior. We have proposed that people with a high level of "awareness of consequences" and "subjective norm" will also have a high level of "personal ecological norms" and a good "attitude toward SAP". Whereas high level "personal ecological norms" together with a good "attitude toward SAP" and "perceived behavioral control" will lead to an "intention to adopt SAP". Then, this intention can push them to directly take action or to do it via more interaction with their network members and begin to use practices that are sustainable for the environment. The last proposition states that the higher the farmer's institutional trust, the better the association between their intention and their adoption of SAP. A hypothesis will come from the different propositions and then be empirically tested in future research.

Author Contributions: Conceptualization, T.P.C. and J.D.; investigation, T.P.C. and D.D.; writingoriginal draft preparation, T.P.C.; writing-review and editing, T.P.C., J.D., O.J.A., D.D. and E.K.; supervision, J.D.; project administration, T.P.C.; funding acquisition, J.D. All authors have read and agreed to the published version of the manuscript.

Funding: This research was funded by Key Research Base of Universities in Jiangsu Province for Philosophy and Social Science "Research Center for Green Development and Environmental Governance", and supported in part by the National Science Foundation of China under grants 71704066, 71971100, and 71974081.

Conflicts of Interest: The authors declare no conflict of interest. The funders had no role in the design of the study; in the collection, analyses, or interpretation of data; in the writing of the manuscript, or in the decision to publish the results.

\section{References}

1. Tilman, D.; Fargione, J.; Wolff, B.; D'Antonio, C.; Dobson, A.; Howarth, R.; Schindler, D.; Schlesinger, W.H.; Simberloff, D.; Swackhamer, D. Forecasting Agriculturally Driven Global Environmental Change. Science 2001, 292, 281-284. [CrossRef]

2. Fuentes, M.; Saba, V. Explaining Ocean Warming: Causes, Scale, Effects and Consequences; IUCN: Gland, Switzerlan, 2016; pp. 289-302.

3. Godfray, H.C.J.; Beddington, J.R.; Crute, I.R.; Haddad, L.; Lawrence, D.; Muir, J.F.; Pretty, J.; Robinson, S.; Thomas, S.M.; Toulmin, C. Food Security: The Challenge of Feeding 9 Billion People. Science 2010, 327, 812-818. [CrossRef]

4. Hansen, J.W. Is Agricultural Sustainability a Useful Concept? Agric. Syst. 1996, 50, 117-143. [CrossRef]

5. MacRae, R.J.; Hill, S.B.; Mehuys, G.R.; Henning, J. Farm-Scale Agronomic and Economic Conversion from Conventional to Sustainable Agriculture11Ecological Agriculture Projects Research Paper No. 9. In Advances in Agronomy; Brady, N.C., Ed.; Academic Press: Cambridge, MA, USA, 1990; Volume 43, pp. 155-198, ISBN 00652113. 
6. Francis, C.A.; Sander, D.; Martin, A. Search for a Sustainable Agriculture: Reduced Inputs and Increased Profits. Crop. Soils 1987, $39,12-14$.

7. Harwood, R.R. A history of sustainable agriculture. In Sustainable Agricultural Systems; Soil and Water Conservation Society: Ankeny, IA, USA, 1990; pp. 3-19, ISBN 9780935734218.

8. Brodt, S.; Six, J.; Feenstra, G.; Ingels, C.; Campbell, D. Sustainable Agriculture. Nat. Educ. Knowl. $2011,3,1$.

9. McGuire, S. FAO, IFAD, and WFP. The State of Food Insecurity in the World 2015: Meeting the 2015 International Hunger Targets: Taking Stock of Uneven Progress. Rome: FAO, 2015. Adv. Nutr. 2015, 6, 623-624. [CrossRef]

10. Coulibaly, P.T.; Du, J.; Dabuo, F.T.; Akouatcha, G.H. The Effect of Farmers Social Networks on Sustainable Agricultural Practices Adoption: A Scoping Review Protocol. Int. J. Sustain. Agric. Res. 2021, 8. [CrossRef]

11. Trinh, T.Q.; Rañola, R.F.; Camacho, L.D.; Simelton, E. Determinants of Farmers' Adaptation to Climate Change in Agricultural Production in the Central Region of Vietnam. Land Use Policy 2018, 70, 224-231. [CrossRef]

12. Borras, S.M.; Franco, J.C.; Suárez, S.M. Land and Food Sovereignty. Third World Q. 2015, 36, 600-617. [CrossRef]

13. Nmadu, J.; Omojeso, B.; Sallawu, H. Socio-economic factors affecting adoption of innovations by cocoa farmers in ondo state, nigeria. Eur. J. Bus. Econ. Account. 2015, 3, 58.

14. Ng'ombe, J.; Kalinda, T.; Tembo, G.; Kuntashula, E. Econometric Analysis of the Factors That Affect Adoption of Conservation Farming Practices by Smallholder Farmers in Zambia. J. Sustain. Dev. 2014, 7. [CrossRef]

15. Gilbert, N. Agent-Based Models; SAGE Publications: Los Angeles, CA, USA; London, UK; New Delhi, India; Singapore, 2008.

16. Teklewold, H.; Kassie, M.; Shiferaw, B.; Köhlin, G. Cropping System Diversification, Conservation Tillage and Modern Seed Adoption in Ethiopia: Impacts on Household Income, Agrochemical Use and Demand for Labor. Ecol. Econ. 2013, 93, 85-93. [CrossRef]

17. Dessart, F.J.; Barreiro-Hurlé, J.; Van Bavel, R. Behavioural Factors Affecting the Adoption of Sustainable Farming Practices: A Policy-Oriented Review. Eur. Rev. Agric. Econ. 2019, 46, 417-471. [CrossRef]

18. Saptutyningsih, E.; Diswandi, D.; Jaung, W. Does Social Capital Matter in Climate Change Adaptation? A Lesson from Agricultural Sector in Yogyakarta, Indonesia. Land Use Policy 2019, 95, 104189. [CrossRef]

19. Baloch, M.A.; Thapa, G.B. The Effect of Agricultural Extension Services: Date Farmers' Case in Balochistan, Pakistan. J. Saudi Soc. Agric. Sci. 2018, 17, 282-289. [CrossRef]

20. Damalas, C.; Koutroubas, S. Farmers' Training on Pesticide Use Is Associated with Elevated Safety Behavior. Toxics 2017, 5, 19. [CrossRef]

21. Ferroni, M.; Castle, P. Public-Private Partnerships and Sustainable Agricultural Development. Sustainability 2011, 3, 1064-1073. [CrossRef]

22. Rajendran, N.; Tey, Y.S.; Brindal, M.; Sidique, S.; Shamsudin, M.N.; Radam, A.; Abdul Hadi, A.H. Factors Influencing the Adoption of Bundled Sustainable Agricultural Practices: A Systematic Literature Review. Int. Food Res. J. 2016, 23, $2271-2279$.

23. Akintunde, E. Theories and Concepts for Human Behavior in Environmental Preservation. J. Environ. Sci. Public Health 2017, 1, 120-133. [CrossRef]

24. Darnton, A. Practical Guide: An Overview of Behaviour Change Models and Their Uses; Government Social Research Unit: London, UK, 2008.

25. Jackson, T. Motivating Sustainable Consumption: A Review of Evidence on Consumer Behaviour and Behavioural Change. Sustain. Dev. Res. Netw. 2005, 15, 30-40.

26. Han, H.; Hwang, J.; Lee, M.J.; Kim, J. Word-of-Mouth, Buying, and Sacrifice Intentions for Eco-Cruises: Exploring the Function of Norm Activation and Value-Attitude-Behavior. Tour. Manag. 2019, 70, 430-443. [CrossRef]

27. Si, H.; Shi, J.-G.; Tang, D.; Wen, S.; Miao, W.; Duan, K. Application of the Theory of Planned Behavior in Environmental Science: A Comprehensive Bibliometric Analysis. Int. J. Environ. Res. Public Health 2019, 16, 2788. [CrossRef] [PubMed]

28. Fishbein, M.; Ajzen, I. Belief, Attitude, Intention and Behaviour: An Introduction to Theory and Research; Addison Wesley Co.: Boston, MA, USA, 1975; Volume 27.

29. Ajzen, I. The Theory of Planned Behavior. Organ. Behav. Hum. Decis. Process. 1991, 50, 179-211. [CrossRef]

30. Asare, M. Using the theory of planned behavior to determine the condom use behavior among college students. Am. J. Health Stud. 2015, 30, 43-50.

31. Ajzen, I. Perceived Behavioral Control, Self-Efficacy, Locus of Control, and the Theory of Planned Behavior1. J. Appl. Soc. Psychol. 2002, 32, 665-683. [CrossRef]

32. Schwartz, S.H. Normative Influences on Altruism; Berkowitz, L.B.T.-A., Ed.; Academic Press: Cambridge, MA, USA, 1977; Volume 10, pp. 221-279, ISBN 00652601.

33. de Groot, J.; Steg, L. Morality and Prosocial Behavior: The Role of Awareness, Responsibility, and Norms in the Norm Activation Model. J. Soc. Psychol. 2009, 149, 425-449. [CrossRef] [PubMed]

34. Paço, A. Prosocial Behavior and Sustainable Development. In Encyclopedia of Sustainability in Higher Education; Leal Filho, W., Ed.; Springer International Publishing: Cham, Switzerland, 2019; pp. 1321-1325, ISBN 9783030113520.

35. Piñeiro, V.; Arias, J.; Dürr, J.; Elverdin, P.; Ibáñez, A.M.; Kinengyere, A.; Opazo, C.M.; Owoo, N.; Page, J.R.; Prager, S.D.; et al. A Scoping Review on Incentives for Adoption of Sustainable Agricultural Practices and Their Outcomes. Nat. Sustain. 2020, 3 , 809-820. [CrossRef] 
36. Jitsanguan, T. Sustainable Agriculture Systems for Small-Scale Farmers in Thailand: Implications for the Environment; Food and Fertilizer Technology Center: Kawana, Japan, 2001.

37. Park, J.; Ha, S. Understanding Consumer Recycling Behavior: Combining the Theory of Planned Behavior and the Norm Activation Model. Fam. Consum. Sci. Res. J. 2014, 42, 278-291. [CrossRef]

38. Huijts, N.M.A.; Molin, E.J.E.; Steg, L. Psychological Factors Influencing Sustainable Energy Technology Acceptance: A ReviewBased Comprehensive Framework. Renew. Sustain. Energy Rev. 2012, 16, 525-531. [CrossRef]

39. Tokunaga, K.; Sugino, H.; Nomura, H.; Michida, Y. Norms and the Willingness to Pay for Coastal Ecosystem Restoration: A Case of the Tokyo Bay Intertidal Flats. Ecol. Econ. 2020, 169, 106423. [CrossRef]

40. Harland, P.; Staats, H.; Wilke, H.A.M. Explaining Proenvironmental Intention and Behavior by Personal Norms and the Theory of Planned Behavior1. J. Appl. Soc. Psychol. 1999, 29, 2505-2528. [CrossRef]

41. Kohler, H.-P. Learning in Social Networks and Contraceptive Choice. Demography 1997, 34, 369-383. [CrossRef]

42. Palloni, A. Diffusion in Sociological Analysis. In International Encyclopedia of the Social and Behavioral Sciences, 2nd ed.; Wright, J., Ed.; Elsevier: Oxford, UK, 2015; pp. 411-416, ISBN 978-0080970875.

43. Wang, G.; Lu, Q.; Capareda, S.C. Social Network and Extension Service in Farmers' Agricultural Technology Adoption Efficiency. PLOS ONE 2020, 15, e0235927.

44. Kim, M.; Fernandez, R.M. Strength Matters: Tie Strength as a Causal Driver of Networks' Information Benefits. Soc. Sci. Res. 2017, 65, 268-281. [CrossRef] [PubMed]

45. Granovetter, M.S. The Strength of Weak Ties. Am. J. Sociol. 1973, 78, 1360-1380. [CrossRef]

46. Wossen, T.; Berger, T.; Mequaninte, T.; Alamirew, B. Social Network Effects on the Adoption of Sustainable Natural Resource Management Practices in Ethiopia. Int. J. Sustain. Dev. World Ecol. 2013, 20, 477-483. [CrossRef]

47. Ramirez, A. The Influence of Social Networks on Agricultural Technology Adoption. Procedia Soc. Behav. Sci. 2013, 79, 101-116. [CrossRef]

48. Todo, Y.; Matous, P.; Mojo, D. Effects of Social Network Structure on the Diffusion and Adoption of Agricultural Technology: Evidence from Rural Ethiopia. SSRN 2014. [CrossRef]

49. Joffre, O.M.; De Vries, J.R.; Klerkx, L.; Poortvliet, P.M. Why Are Cluster Farmers Adopting More Aquaculture Technologies and Practices? The Role of Trust and Interaction within Shrimp Farmers' Networks in the Mekong Delta, Vietnam. Aquaculture 2020, 523. [CrossRef]

50. Luhmann, N. Trust and Power Cichester; Wiley: Hoboken, NJ, USA, 2020.

51. Gefen, D.; Straub, D.W. Consumer Trust in B2C E-Commerce and the Importance of Social Presence: Experiments in e-Products and e-Services. Omega 2004, 32, 407-424. [CrossRef]

52. Six, F.; Nooteboom, B.; Hoogendoorn, A. Actions That Build Interpersonal Trust: A Relational Signalling Perspective. Rev. Soc. Econ. 2010, 68, 285-315. [CrossRef]

53. PytlikZillig, L.M.; Kimbrough, C.D.; Shockley, E.; Neal, T.M.S.; Herian, M.N.; Hamm, J.A.; Bornstein, B.H.; Tomkins, A.J. A Longitudinal and Experimental Study of the Impact of Knowledge on the Bases of Institutional Trust. PLoS ONE 2017, 12, e0175387. [CrossRef]

54. Taniguchi, H.; Marshall, G.A. Trust, Political Orientation, and Environmental Behavior. Environ. Politics 2018, 27, 385-410. [CrossRef]

55. Tsang, S.; Burnett, M.; Hills, P.; Welford, R. Trust, Public Participation and Environmental Governance in Hong Kong. Environ. Policy Gov. 2009, 19, 99-114. [CrossRef]

56. Camp, W. Formulating and Evaluating Theoretical Frameworks for Career and Technical Education Research. J. Vocat. Educ. Res. 2001, 26, 4-25. [CrossRef]

57. Liehr, P.; Smith, M. Middle Range Theory: Spinning Research and Practice to Create Knowledge for the New Millennium. Adv. Nurs. Sci. 1999, 21, 81-91. [CrossRef]

58. Peshkin, A. The Goodness of Qualitative Research. Educ. Res. 1993, 22, 23-29. [CrossRef]

59. Ajzen, I. The Theory of Planned Behaviour: Reactions and Reflections. Psychol. Health 2011, 26, 1113-1127. [CrossRef]

60. Sumaedi, S.; Yarmen, M.; Bakti, I.G.M.Y.; Rakhmawati, T.; Astrini, N.J.; Widianti, T. The Integrated Model of Theory Planned Behavior, Value, and Image for Explaining Public Transport Passengers' Intention to Reuse. Manag. Environ. Qual. Int. J. 2016, 27, 124-135. [CrossRef]

61. Jacobs, N.; Hagger, M.; Streukens, S.; Bourdeaudhuij, I.; Claes, N. Testing an Integrated Model of the Theory of Planned Behaviour and Self-Determination Theory for Different Energy Balance-Related Behaviours and Intervention Intensities. Br. J. Health Psychol. 2011, 16, 113-134. [CrossRef] [PubMed]

62. Liu, Y.; Sheng, H.; Mundorf, N.; Redding, C.; Ye, Y. Integrating Norm Activation Model and Theory of Planned Behavior to Understand Sustainable Transport Behavior: Evidence from China. Int J. Env. Res. Public Health 2017, 14, 1593. [CrossRef] [PubMed]

63. Setiawan, B.; Afiff, A.Z.; Heruwasto, I. Integrating the Theory of Planned Behavior With Norm Activation in a Pro-Environmental Context. Soc. Mark. Q. 2020, 26, 244-258. [CrossRef]

64. Rezaei, R.; Safa, L.; Damalas, C.A.; Ganjkhanloo, M.M. Drivers of Farmers' Intention to Use Integrated Pest Management: Integrating Theory of Planned Behavior and Norm Activation Model. J. Environ. Manag. 2019, 236, 328-339. [CrossRef] 
65. Bamberg, S.; Möser, G. Twenty Years after Hines, Hungerford, and Tomera: A New Meta-Analysis of Psycho-Social Determinants of pro-Environmental Behaviour. J. Environ. Psychol. 2007, 27, 14-25. [CrossRef]

66. Yazdanpanah, M.; Forouzani, M. Application of the Theory of Planned Behaviour to Predict Iranian Students' Intention to Purchase Organic Food. J. Clean. Prod. 2015, 107, 342-352. [CrossRef]

67. Ng, K.Y.N. The Moderating Role of Trust and the Theory of Reasoned Action. J. Knowl. Manag. 2020, 24, 1221-1240. [CrossRef]

68. Kim, S.H.; Seock, Y.-K. The Roles of Values and Social Norm on Personal Norms and Pro-Environmentally Friendly Apparel Product Purchasing Behavior: The Mediating Role of Personal Norms. J. Retail. Consum. Serv. 2019, 51, 83-90. [CrossRef]

69. Thøgersen, J. Norms for Environmentally Responsible Behaviour: An Extended Taxonomy. J. Environ. Psychol. 2006, 26, $247-261$. [CrossRef]

70. Zhang, X.; Geng, G.; Sun, P. Determinants and Implications of Citizens' Environmental Complaint in China: Integrating Theory of Planned Behavior and Norm Activation Model. J. Clean. Prod. 2017, 166, 148-156. [CrossRef]

71. Bamberg, S.; Rees, J. Environmental Attitudes and Behavior: Measurement. In International Encyclopedia of the Social and Behavioral Sciences, 2nd ed.; Elsevier: Amsterdam, The Netherlands, 2015; pp. 699-705, ISBN 9780080970875.

72. Han, H. The Norm Activation Model and Theory-Broadening: Individuals' Decision-Making on Environmentally-Responsible Convention Attendance. J. Environ. Psychol. 2014, 40, 462-471. [CrossRef]

73. Janssen, M.; Ostrom, E.; Tesfatsion, L.; Judd, K. Governing Social-Ecological Systems. Handbook of Computational Economics II: Agent-Based Computational Economics; Elsevier: Amsterdam, The Netherlands, 2006.

74. Nordlund, A.; Garvill, J. Effects of Values, Problem Awareness, and Personal Norm on Willingness to Reduce Personal Car Use. J. Environ. Psychol. 2003, 23, 339-347. [CrossRef]

75. Bamberg, S.; Hunecke, M.; Blöbaum, A. Social Context, Personal Norms and the Use of Public Transportation: Two Field Studies. J. Environ. Psychol. 2007, 27, 190-203. [CrossRef]

76. Thøgersen, J.; Ölander, F. The Dynamic Interaction of Personal Norms and Environment-Friendly Buying Behavior: A Panel Study1. J. Appl. Soc. Psychol. 2006, 36, 1758-1780. [CrossRef]

77. Asadi, S.; Hussin, A.R.C.; Dahlan, H.M.; Yadegaridehkordi, E. Theoretical Model for Green Information Technology Adoption. J. Eng. Appl. Sci. 2015, 10, 17720-17729.

78. Mastrangelo, M.; Gavin, M.; Laterra, P.; Linklater, W.; Milfont, T. Psycho-Social Factors Influencing Forest Conservation Intentions on the Agricultural Frontier. Conserv. Lett. 2013, 7. [CrossRef]

79. Barlett, C.P. Social Psychology Theory Extensions; Academic Press: Cambridge, MA, USA, 2019; Chapter 5; pp. 37-47, ISBN 9780128166536.

80. Mafabi, S.; Nasiima, S.; Muhimbise, E.M.; Kasekende, F.; Nakiyonga, C. The Mediation Role of Intention in Knowledge Sharing Behavior. Vine J. Inf. Knowl. Manag. Syst. 2017, 47, 172-193. [CrossRef]

81. Octav-Ionut, M. Applying the Theory of Planned Behavior in Predicting Pro- Environmental Behaviour: The Case of Energy Conservation. Acta Univ. Danub. CEcon. 2015, 11, 15-32.

82. Dalvi Esfahani, M.; Nilashi, M.; Rahman, A.A.; Ghapanchi, A.H.; Zakaria, N.H. Psychological Factors Influencing the Managers' Intention to Adopt Green IS: A Review-Based Comprehensive Framework and Ranking the Factors. Int. J. Strateg. Decis. Sci. 2015. [CrossRef]

83. Zhang, L.; Hu, Q.; Zhang, S.; Zhang, W. Understanding Chinese Residents' Waste Classification from a Perspective of IntentionBehavior Gap. Sustainability 2020, 12, 4135. [CrossRef]

84. Tepic, M.; Trienekens, J.; Hoste, R.; Omta, O. The Influence of Networking and Absorptive Capacity on the Innovativeness of Farmers in the Dutch Pork Sector. Int. Food Agribus. Manag. Rev. 2012, 15.

85. Reagans, R.; McEvily, B. Network Structure and Knowledge Transfer: The Effects of Cohesion and Range. Adm. Sci. Q. 2003, 48, 240-267. [CrossRef]

86. Carley, K. Knowledge Acquisition as a Social Phenomenon. Instr. Sci. 1986, 14, 381-438. [CrossRef]

87. Mcknight, D.; Chervany, N. Trust and Distrust Definitions: One Bite at a Time. In Trust in Cyber-Societies; Springer: Berlin/Heidelberg, Germany, 2001; Volume 2246, pp. 27-54.

88. Jia, X.; James, H.S. Organizational Trust in Farmer Organizations: Evidence from the Chinese Fresh Apple Industry. Br. Food J. 2018, 120, 676-689. [CrossRef]

89. Rehman, S.; Bhatti, A.; Mohamed, R.; Ayoup, H. The Moderating Role of Trust and Commitment between Consumer Purchase Intention and Online Shopping Behavior in the Context of Pakistan. J. Glob. Entrep. Res. 2019, 9. [CrossRef]

90. Moon, S.-G.; Jeong, S.; Choi, Y. Moderating Effects of Trust on Environmentally Significant Behavior in Korea. Sustainability 2017, 9, 415. [CrossRef] 